\title{
The Importance of School-Family Communication in the Teachers' Point of View in Albania
}

\author{
Ardian Tana \\ PhD Candidate, "Alexandër Xhuvani" University, \\ Elbasan, Albania \\ ardiantana@yahoo.it
}

\section{Doi:10.5901/jesr.2014.v4n1p273}

\begin{abstract}
To fulfil its mission the school has to collaborate with the student's parents and the community. In the school-family partnership, each of the actors has an important role to play. In the way that this partnering functions at its best, firstly, the families and the school have to communicate through a two-way communication, which is based in the relationship of reciprocal faith and respect. In Albania, as in other former-communist countries, the school-family communication has been a new tradition and not consolidated yet. This work aims to highlight the evaluation of Albanian teachers for the school-family process of communication and mainly its role in the pupil's achievements and the improvement of their behaviour through the analysis done from the findings of a questionnaire realised with the high-school system level teachers.
\end{abstract}

Keywords: school-family communication, two-way communication, pupils' achievements, improvement of pupils' behaviour

\section{Introduction}

Day after day school is becoming more and more aware concerning their collaboration with the families. Epstein (2001) underlines that, "No topic about school improvement has created rhetoric than "parent involvement". Everyone says that it is important. In study after study, teachers, administrators, and even students from elementary through high school say that involvement benefits students, improves schools, assists teachers, and strengthen families" (p. 3).

If school itself has a philosophy and clear attitudes-views about the involvement of parents, then, they have the opportunity to benefit from this important source to improve their work and pupils' achievements.

The difference of socio-economic circumstances has consequently brought the difference of school-family relationship, as the only organisms that are too sensitive to these changes. Over the years changes have occurred not only in their evaluation or to the theoretical supporting ground, but also to the enabling of these relationships in practice.

\subsection{Parents' involvement in school's life}

According to Christenson \& Sheridan (2001), "The goal of family involvement with education is not merely to get families involved, but rather to connect important contexts for strengthening children's learning and development" (p. 7).

The teacher finds it indispensable to be aware of the conditions in which is raised and lives his pupil, his strong points and what does disturb him, his desires or needs. All this information is an irreplaceable source for a successful teaching. The teacher can provide this information only through collaboration and co-operation with the pupil's parents, who may also be strong supporters of the work that is done in the class and with the help that they may give with the homework or other activities in home. Parents with their knowledge and their experience can be an added value for the school itself.

From early times, evaluated as an important asset for the education success, the case of parents' involvement in the school's life and more widely the school-family partnering, has drawn the attention of many scholars.

An appropriate partnership should involve in itself the expectations and the point of view of each of the partners (Dunst, 1992; Pourtois \& Desmet, 1997). It should be based in the principle of equality of each party: the parents and the teachers have special knowledge and experiences to share with one another.

As Epstein underlines (2002), "The way schools care about children is reflected in the way schools care about children's families. If educators view children simply as students, they are likely to see the family as separate from the school. If educators view children as children, they are likely to see both the family and community as partners with the 
school in children's education and development" (p. 20).

The parents who are a little involved frequently start to get involved actively when their children's school has comprehensive policies, which make them feel appraised, encouraged and supported (Lewis \& Henderson, 1997).

School is the one that has to compile programs and to promote collaboration with parents and of course they have to make the first step in the leadership of this collaboration, because schools have the priority in energy and sources.

\subsection{Albanian reality}

In Albania, as in many other former-communist countries, the tradition of involvement of parents in the school life is new. Until the beginning of the 1990s the school kept the families away, considering the education as their only attribute, promoted this from the strong effect of politics and the centralisation that this last one made to the children and youth's education in its ideological function. In the same way, parents considered education as a right only of the school and did not see themselves as part of their children's education. In this way, between the school and the families was created a great gap which till after more than 20 years has not been filled properly. Throughout these years from their part the legislative have compiled a legislation which reflects the world's best experience and the local experience in management of the partnering school-family. So, in the law for the pre-university education system in the Republic of Albania is stated clearly the evaluation of involvement of parents. "Parents are the main partner to the education institution for the progress of their child and the institution itself" (Article 62). ${ }^{1}$

But, is this all enough? The institutionalisation of the relationship school-family is an important and indispensable step. Beyond this, should be created the right environment for the functioning of this partnering and the school and other institutions in the field of education should do more. The first step is setting of two side bridges of communication between school and family.

\section{The Two-Way Communication is the Key to Success}

According to Boufard (2008) communication is at the heart of family-school relationships. To make the functioning of the partnering school-family possible, above all is required communication among them, a continuous, sincere, reliable and a two-way communication.

Communication between home and school is an essential component of parental involvement and the ultimate goal of increased student achievement (Akmal\&Larsen, 2004; Bouffard, 2008; Epstein, 2001\&2008; Simon, 2004).

According to Epstein (2001) the main aim of this partnering is to develop and conduct a better communication with the families throughout the school years to support the student towards his success in school.

Weiss and Edwards (1992) emphasize that one of the main aims of communication is to provide continuous messages for the family, so that, the school to work with them in a collaborative way to promote the success in the education of their children.

Effective and continuous communication is indispensable, because it is required both from the teachers and the parents to share the same information about the performance of the student in school, his needs and interests. Through this two-way communication parents and teachers can be informed on about what is expected from the student's behaviour, achievement and discipline.

At communicating with one another, parents and teachers share among them the common aims for the performance of the child in school and his growth, take common decisions, avoid misunderstandings and help parents to understand how they can reinforce learning and the school's instructions in home.

\subsection{How do Albanian teachers evaluate the school-family communication?}

In a study which I realised in one of the cities of Albania, in Elbasan, with 300 teachers in public and non-public schools, in the city and in the countryside, it is aimed to get the teachers' perceptions about the school-family communication, the role of parents in the life of school and especially their impact in the improvement of the students results and behaviour at school.

$94 \%$ of the teachers give lesson in public schools (281 teachers), whereas $6 \%$ of them give lesson in non-public schools (91 teachers); $61.4 \%$ of them were teachers in schools in the city (181 teachers), and $38.6 \%$ were teachers in

${ }^{1}$ Www.qbz.gov.al, Article no. 69/2012 
rural schools (38.6\%).

To the question about how the teachers do evaluate the communication with the parents regarding its impact in the students' achievements over $91 \%$ of them evaluate it as helpful and too helpful; whereas $8.7 \%$ of them evaluate it somewhat helpful. So, it is clear that without exception the teachers nearly evaluate the usefulness of communication with parents.

Table 1: Evaluation about the communicating with parents

\begin{tabular}{|l|c|c|}
\hline \multicolumn{1}{|c|}{ Answers } & Frequency & Percentage \\
\hline Not at all helpful & 1 & 0.3 \\
Somewhat helpful & 27 & 9.0 \\
Helpful & 81 & 27.0 \\
Very helpful & 191 & 63.7 \\
\hline
\end{tabular}

In the same way, a positive evaluation about the school-family communication is derived from the question if the parentteacher communication does not affect to their work which, in fact, is a question addressed to teachers, $83 \%$ of whom do not agree at all with it, $6.3 \%$ do at somewhat agree, $6 \%$ are insecure about it and only $4.6 \%$ of the teachers do agree. The results show almost the same conclusions, a thing that proves the evaluation that teachers themselves have about the usefulness of parent-teacher communication.

Table 2: Parent-teacher communication does not have an effect on my work as a teacher

\begin{tabular}{|l|c|c|}
\hline \multicolumn{1}{|c|}{ Answers } & Frequency & Percentage \\
\hline Do not agree at all & 249 & 83.0 \\
Somewhat agree & 19 & 6.3 \\
Do not know/Insecure & 18 & 6.0 \\
Agree & 14 & 4.6 \\
\hline
\end{tabular}

For this, persuade more the answers derived for the question in reference with the efficiency of teacher-parent communication. $90.5 \%$ of teachers evaluate the communication parent-teacher as efficient, $1.4 \%$ of teachers' estimate it as uncertain, $5.8 \%$ evaluate it as somewhat efficient and only $1 \%$ of them do not evaluate this communication as efficient.

Table 3: Communication parent-teacher is not at all effective

\begin{tabular}{|l|c|c|}
\hline \multicolumn{1}{|c|}{ Answers } & Frequency & Percentage \\
\hline Do not agree at all & 271 & 90.4 \\
Somewhat agree & 17 & 5.6 \\
Do not know/Insecure & 9 & 3.0 \\
Agree & 3 & 1.0 \\
\hline
\end{tabular}

Asked about the issue about which teachers mostly communicate with parents, they express that these contacts are realised mostly for the students learning achievements (93.6\%) and about the student behaviour (80.6\%), whereas the issue of the lesson overload, curricula, etc., takes an overload smaller (65.1\%).

Teachers estimate with a high percentage the communication parent-teacher in the achievement of students. So, $76 \%$ of the teachers do agree that parent-teacher communication affects the achievements of students, $3 \%$ do somehow agree, $20.7 \%$ do express uncertain and only $0.3 \%$ think that it does not have an impact to the pupils' achievements.

Table 4: Parent-teacher communication affects the pupils' achievements

\begin{tabular}{|l|c|c|}
\hline \multicolumn{1}{|c|}{ Answers } & Frequency & Percentage \\
\hline Do not agree at all & 1 & 0.3 \\
Somewhat agree & 9 & 3.0 \\
Do not know/Insecure & 62 & 20.7 \\
Agree & 228 & 76.0 \\
\hline \multicolumn{2}{|c}{} \\
& 275
\end{tabular}


In the same way teachers are expressed that communication affects positively to the pupils' behaviour and to this do agree $73.7 \%$ of the teachers questioned, $3.3 \%$ do somewhat agree, whereas $23 \%$ express themselves as uncertain.

Table 5: Parent-teacher communication affects positively the pupils' behaviour

\begin{tabular}{|l|c|c|}
\hline \multicolumn{1}{|c|}{ Answers } & Frequency & Percentage \\
\hline Do not agree at all & 0 & 0 \\
Somewhat agree & 10 & 3.3 \\
Do not know/Insecure & 69 & 23.0 \\
Agree & 221 & 73.7 \\
\hline
\end{tabular}

The same results derived from the teachers' answers concerning the impact that parent-teacher communication has to pupils' achievements and the improvement of their behaviour attitude, reinforce the assurance for the positive evaluation that teachers do have in reference to the influence this communication has in school life and especially to the students' performance.

$74 \%$ of teachers evaluate that parents do understand their children's problems and only $6.2 \%$ of the teachers think that parents do not understand these problems (the rest of them, 19.2\% think that this happens rarely).

On the other side, teachers do estimate to the extent $60 \%$ the readiness of parents to collaborate with the school and only $9.3 \%$ of them think that it does never happen or that it happens very rarely.

Table 6: Parents collaborate with the school

\begin{tabular}{|l|c|c|}
\hline \multicolumn{1}{|c|}{ Answers } & Frequency & Percentage \\
\hline Never & 7 & 2.3 \\
Very rarely & 21 & 7.0 \\
Rarely & 91 & 30.3 \\
Usually & 94 & 31.3 \\
Often & 66 & 22.0 \\
Very often & 21 & 7.0 \\
\hline
\end{tabular}

In the teachers' estimation, parents have interests for their children's results (79.7\% of teachers express that parents are interested or very interested and only $3.4 \%$ of them do think that this never happen, or that it happens very rarely).

For a good part of teachers, communication with parents is worth, because through it they receive the necessary information about the weak and strong points of their child ( $47.7 \%$ of them answer that they often receive information worth from parents, $6 \%$ estimate that this does never happen, $13 \%$ emphasize that this happens very rarely, whereas $33.3 \%$ estimate that this happens rarely).

Table 7: Parents transmit valuable information for the strong and weak points of the child

\begin{tabular}{|l|c|c|}
\hline \multicolumn{1}{|c|}{ Answers } & Frequency & Percentage \\
\hline Never & 18 & 6.0 \\
\hline Very rarely & 39 & 13.0 \\
\hline Rarely & 100 & 33.3 \\
\hline Usually & 71 & 23.7 \\
\hline Often & 50 & 16.7 \\
\hline Very often & 22 & 7.3 \\
\hline
\end{tabular}

Estimated from the part of teachers is the readiness of parents support in the cases when pupils show a problematic behaviour ( $77 \%$ of the teachers express estimation about the parents' commitment and only $9.3 \%$ of them do think that this does never happen, or happens very rarely, whereas the rest of them are expressed uncertain).

Questioned about the lack of involvement of parents from the teachers in solving of the problems about the students behaviour $81.3 \%$ emphasize that they do not agree at all with that, only $7 \%$ emphasize that they do not involve parents, $13.6 \%$ emphasize that they do at somewhat agree with this conclusion and $4.4 \%$ are uncertain about this. The given answers express a high commitment of teachers for the parent involvement in the solving of problems with the students. 


\section{Conclusions}

What is seen from the comparison of the results derived from the questionnaire is a kind of difference between the evaluation of the advantage of parent-teacher communication and its reality on the ground implementation. As the teachers estimate the school-family communication in a high percentage as important (over 90\%), in their estimation about the functioning on the ground of this communication are seen great differences. So, only $47.7 \%$ of the teachers are expressed that they take this information from parents as useful, or only $60.7 \%$ of them do evaluate the commitment of parents to collaborate with the school.

From the other side, teachers emphasize that they feel themselves capable to communicate with parents, but do not have the same evaluation for the parents' skills.

More than half of the teachers pretend that are trained to communicate effectively with the parents (59.2\%).

On the other hand $86.1 \%$ teachers said that they are so interested to collaborate with the parents and only $2.7 \%$ of them do not show this commitment (the rest of them are undecided for their answer). At the same time, they do not consider the lectures' load and their efforts at work as an obstacle for the collaboration with parents: $67.5 \%$ of them do not agree at all with this, whereas only $2.4 \%$ do evaluate the lesson loads and their time of work as an obstacle for the collaboration itself, whereas the rest of them do at somewhat agree or are uncertain.

It seems that beyond the evaluation of utility and theoretical commitment shown to collaborate and to communicate with parents, there is great gap for its realisation in practice.

It is time to go from rhetoric to concrete actions.

School and the local scholastic authorities must do more for the realisation of two-side school-family communication. According to Lott (2001), "to wait from parents' part that are a little involved, the filling of this gap without help and encouragement, is not realistic and a strategy of "victims' incrimination".

On the other side, the policy making authorities must not be satisfied only with the drafting of a legal framework, which in the direction of school-family partnering has made great progress approaching countries with more great experience in this direction, but, we should find the right mechanisms to control it functioning in location.

The teachers' trainings in the teaching faculties should involve in a greater mass the professional qualification of teachers for the communication with families.

The training programmes of parents about the school-family partnering and the communication between them must be part of the school programmes in the future.

\section{References}

Akmal, T. T., \& Larsen, D. E. (2004). Keeping history from repeating itself: Involving parents about retention decisions to support student achievement. RMLE Online: Research in Middle Level Education, 27 (2).

Boufard, S. (2008). Topping into technology: The role of the internet in family-school communication. Harvard Family Research Project; Harvard Graduate School of Education parent involvement in secondary-level schooling.

Christenson L. S., \& Sheridan M. S. (2001). School and families creating essential connections for learing

Dunst, C. J., Johanson, C., Rounds, T., Trivette, C. M., \& Hamby, D. (1992). Characteristics of parent-professional partnerships.

Epstein, J. L. (2001). School, family, and community partnerships-Preparing educators and improving schools

Epstein, J. L., Sanders, M. G., Simon, B. S., Salinas, K. C., Jansorn, N. J., Van Voorhis, F. L., (2002). School, family and community partnerships.

Georgiu, S. N., \& Tourva, A. (2007). Parental attributions and parental involvement. Social Psychology of Education, 10 (4), $473-482$.

Lewis, A. C., \& Henderson, A. T. (1997). Urgent message: Families crucial to school reform. Washington, DC: Center for Law and Education.

Lott, B (2001). Low income parents and the public school, Journal of Social Issues, 57, 247-259.

McCoach, D., Goldstein, J., Behuniak, P., Reis, S., Anne, C., Sullivan, E. E., \& Rambo, K. (2010). Examiningthe unexpected: Outlier analyses of factors affecting student achievement. Journal of Advanced Academic, 21 (3), 462-468.

Simon, B. S. (2004). High school outreach and family involvement. Social Psychology of Education, 7 (2), 185-209.

Weiss, H. M., \& Edwards, M. E. (1992). The family-school collaboration project: Systemic interventions for school improvement. In S. L. Christenson (2002). Collaborative family-school relationships for children's lerning. Virginia Department of Education. 
